\title{
LINKING BIOSECURITY AND BIOGEOGRAPHY
}

\author{
M.K. KAY \\ Scion, Private Bag 3020, Rotorua 3046, New Zealand \\ Corresponding author: nod.kay@scionresearch.com
}

\begin{abstract}
The unfathomable complexity of species interactions within biological systems tempts us to impose tidy concepts in an effort to predict, or explain, how ecosystems react to perturbation through species extinction or invasion. The Equilibrium Theory of Island Biogeography (ETIB) contends that islands are inherently at risk of both invasion and extinction of species. The appealing logic of the ETIB and a general consensus that biodiversity is linked to ecosystem resilience - i.e. that the loss of biodiversity will result in a loss of ecosystem stability - have been cemented into mainstream ecology. However, the biodiversityecosystem resilience debate is far from resolved. The ETIB treats species as empirical entities and takes no account of how species' interactions evolve to determine the way ecosystems function. The Island Resource Allocation (IRA) hypothesis offers a testable alternative explanation of how ecosystems function and could be considered by biosecurity agencies in assessing ecological risk of introduced species.

Keywords: biosecurity, island ecosystems, resource allocation.
\end{abstract}

\section{INTRODUCTION}

Biosecurity agencies within New Zealand are charged with preventing, or managing, further anthropogenic degradation of the extant 'ecosystem' - i.e. they take a protectionist stance to maintaining the status quo of the species interactions that form the production and indigenous ecosystems. Maintaining or managing any system assumes a knowledge of how that system functions. Unfortunately the complexity of potential species interactions within ecosystems means we are far from understanding how ecosystems function (Davies 2005; Hooper et al. 2005), let alone coping with the additions or extinctions that may befall them.

New Zealand's pre-eminence in biosecurity is driven in part by its economic dependence on primary production and tourism, but also on an entrenched dogma of the invasibility of island ecosystems. Island biotas are typically simple and disharmonic (Whittaker 1998). Larger habitats hold a greater diversity of species than smaller habitats, but the relationship is more pronounced on islands (May 1975; Rosenzweig 1995; Holt et al. 1999) and it has been argued that ecosystems with little biodiversity lack 'biotic resistance' to invasive species (Elton 1958; Carlquist 1965; Hooper et al. 2005). The biotic resistance hypothesis contends that the degree of interaction with indigenous species has the potential to prevent the establishment and/or spread of exotic species; with a presumption that greater species diversity leads to greater potential for species interaction. Although considered a strong process by many ecologists (Moulton \& Pimm 1983; Case 1990; Kennedy et al. 2002), the empirical evidence for biotic resistance is weak (Maron \& Vila 2001; Levine et al. 2004; Long et al. 2009).

The invasibility of island ecosystems is plausibly supported by the Equilibrium Theory of Island Biogeography (ETIB), which provides an elegant contention that the simplicity of an island biota is maintained by a dynamic equilibrium between a continuous immigration and extinction of species (MacArthur \& Wilson 1967).

There are abundant and dramatic examples of species invasion and extinction in insular ecosystems colonised by man (e.g. Fritts \& Rhodda 1998), so it is not surprising that 
the vulnerability of island ecosystems has become ingrained in mainstream ecology. Yet islands, and other persistent simple ecosystems such as bogs and arctic lichen communities, are renowned for their endemism, which requires evolutionary time scales of stability.

Ecosystem stability and function is determined by species-level interactions, and an essential failing of the ETIB, and other neutral theories that assume all species have the same equivalence, is their presumption that all ecosystems function in a similar manner. Neutral ecological hypotheses, by definition, are unable to account for the complexities and evolution of species interaction within ecosystems (Hubbell 2001). They are therefore of limited predictive ability when considering cross-trophic species interaction with changes in biodiversity.

Plants and insects are dominant components of terrestrial biodiversity and insects are likely to mediate the transfer of a significant portion of nutrients and energy from the autotrophic (plants) to the heterotrophic components of the community (Weisser \& Siemann 2004). Herbivory can adversely affect plants and the co-evolutionary interaction between insects and plants has been prominent in ecological research for a number of decades (Moore 1995). However, the resulting 'quagmire of plant defence hypotheses' (Stamp 2003) has failed to produce an over-arching plant defence theory (Berenbaum 1995) that would aid predictions for novel insect-plant interactions. Interestingly, the ETIB has been applied to insect-plant interactions. However, the consideration of host plants as islands; the 'apparency' of plant species to insects, and other attempts to relate community structure to the evolution and deployment of plant defences (Strong et al. 1984) have had little predictive success (Lill et al. 2002; Lewinsohn et al. 2005). Here the New Zealand experience with invasive invertebrate defoliators is briefly reviewed and an alternative biogeographic explanation for why it appears contrary to accepted invasive ecological paradigms is offered.

\section{INVERTEBRATE ESTABLISHMENTS}

Despite the best efforts of legislators and biosecurity practitioners, the establishment of exotic invertebrates in New Zealand has continued at a steady rate (Walsh \& Kay 1996; Charles 1998; Ridley et al. 2000; Kriticos et al. 2005). The estimated 2000 alien invertebrate species that have naturalised in New Zealand (Anon. 1997) comprise $90 \%$ of the country's invertebrate pest species - largely because they are associated with primary production industries that are based on Northern Hemisphere plant and animal species. However, of the 216 introduced forest and timber insects, only about $12 \%$ have been recorded from living indigenous forest trees and shrubs (Bain 2003). None, with the exception of the two Eriococcus species, have caused significant damage to indigenous host plants. The two species that did were Australian eriococcids that were essentially attacking their natural hosts, Leptospermum scoparium and Kunzea ericoides (both occur naturally in Australia), in temporarily enemy-free space.

A number of observers have commented that the overall effect of introduced invertebrates on the indigenous ecosystem appears to be minimal (Lowe 1973; Alma 1986; Atkinson \& Cameron 1993; Ridley et al. 2000). This is in stark contrast to similar introductions to more diverse continental biotas. For example, the establishment of the Eurasian gypsy moth, Lymantria dispar, in North America had a profound effect on the indigenous forest (Campbell 1979), while a reciprocal establishment of the North American fall web worm, Hyphantria cunea, had significant impact when it was accidentally introduced into Eurasia in the 1940s (Ito \& Miyashita 1968).

There are a number of potential explanations for this disparity. Propagule pressure is considered to promote establishment and naturalisation of exotic species (Kolar \& Lodge 2001). Trade, and the movement of hitch-hiking insects, are undoubtedly greater between continents than between continents and islands and would raise the chances of establishment. The high endemicity of the island flora (Whittaker 1998) may also provide a significant hurdle for invasive alien species. Insects, even polyphagous species, have host preferences, usually for phylogenetically related plants (Erlich \& Raven 1964; 
Jaenike 1990; Mitter et al. 1991; Kopf et al. 1998). Ecosystem degradation may also assist the establishment of invasive species (D'Antonio \& Dudley 1995) and the later colonisation of islands such as New Zealand may correspond to lesser environmental degradation.

However, at least six controlled bioassays using novel host-herbivore interactions between elements of the New Zealand flora and a range of exotic insect species have shown that plants with limited geographic ranges are resistant to invertebrate defoliators. The exotic insect species tested included gypsy moth (Matsuki et al. 2001); the white spotted tussock moth (Orgyia thyellina) (Ridley et al. 2000); the painted apple moth (Teia anartoides) (Kay 2003); the fall web worm (Kay 2004); the buddleia biological control weevil (Cleopus japonicas) (Kay et al. 2008); and an indigenous defoliator (Pseudocoremia suavis) fed an exotic host (Kay 2006).

\section{PLANT DEFENCE AND SPACE}

A pronounced plant defence in insular plants is contrary to the expectations of the ETIB, invasion ecology and conventional plant defence theories. That plants from islands or small geographic areas were found to be comparatively resistant to continental invertebrate herbivores appears to be counter-intuitive. The accepted paradigms assume that a low diversity of phytophage species in a simple community negates a requirement for metabolically-costly plant defences. However, most plant defence theories neglect the role of tri-trophic interactions. The abundance and distribution of 'predatory' guilds are governed by the same spatial rules as those for herbivores. Species in higher trophic levels are more prone to extinction in smaller habitats so that small habitats not only have fewer species, but they also have a simpler trophic structure (Schoenly et al. 1991; Stireman et al. 2005). Plants in geographically constrained habitats may be exposed to less regulated herbivory and may adopt a bottom-up defence, whereas plants in large habitats may gain a top-down protection from herbivores through a diversity of competing predators. Habitat space may therefore determine an evolutionary reconciliation of the top-down/bottom-up regulation of herbivores.

\section{ECOSYSTEM FUNCTION AND SPACE}

Plant life is limited by an almost universal, but inefficient (net photosynthesis ca $1.2 \%$ efficiency (Meyer et al. 1960)), energy sequestering physiology. The expression of plant traits through natural selection must be derived from resources allocated from this limited pool. An allocation of resources to defence would be at the expense of growth and/or reproduction. If the transfer of energy and nutrients from plants to the heterotrophic community is mediated by insects then a bottom-up defence by plants will have considerable influence on that flux, as the defence mechanism is catabolised throughout the trophic domain. Habitat space may in effect determine the pace of stoichiometric processes within an ecosystem.

The NZ forest flora is noted for its slow growth and limited nutrient up-take (Wardle 1985). That exotic plant species can often be grown faster in New Zealand than almost anywhere else in the world, indicates that the abiotic environment is not a constraint to the growth of indigenous species. An alternative explanation for their slow growth is that the biotic environment is responsible and that insular ecosystems are profoundly different in function when compared to their continental equivalents. It is interesting to note that the colonisation of indigenous plants by exotic fungi in New Zealand (Johnston 2006) shows the same restrained pattern as that of the invertebrates. Thus, the New Zealand indigenous flora appears less assailable than the ETIB would predict.

\section{BIOGEOGRAPHY AND BIOSECURITY}

The Island Resource Allocation (IRA) hypothesis (Kay \& Wratten 2006; Kay 2006) was developed to explain the 'contrary' resistance of the New Zealand indigenous flora to proven invasive defoliators. In essence it posits that geographically constrained plants will invest in bottom-up defences in response to a lack of top-down regulation of herbivores. A corollary of the hypothesis considers that the slow growth of indigenous New Zealand 
plant species is the result of an allocation of plants' resources to defence and that habitat space will have a profound effect on ecosystem function and biosecurity risk.

The exotic plant species supporting the primary production industry in New Zealand invariably originated in complex continental biotas. Not only have they evolved with a complimentary top-down defence, any defence they possessed may have been further reduced by anthropogenic selection for growth, leaving New Zealand's 'crop' species with little innate defence and a concomitant reliance on pesticides. In contrast the indigenous flora appears well defended. In essence this leaves New Zealand's indigenous and introduced floras at opposite ends of the biosecurity risk spectrum, but understanding this conundrum should allow biosecurity agencies to make rational decisions.

The considerable expense of eradicating defoliators perceived as threats to the New Zealand indigenous flora may be better applied to protecting the production flora. The protocols for the introduction of biological control agents for weeds could be less rigorous when considering the threat to indigenous plant species. However, they should be more rigorous with respect to introduced biological control agents for the control of invertebrate pests, because the trophic simplicity of insular habitats may have resulted in a lesser selection for defence in insular invertebrates. Thus, New Zealand's indigenous invertebrates are probably at greater risk to 'colonisation' than the indigenous flora.

Charles (1998) records a substantial 'unassisted' establishment of exotic parasitoids in New Zealand. The entry of these higher trophic levels, especially sophisticated invertebrate predators such as the social Hymenoptera, could well have more serious, albeit indirect, consequences for the indigenous flora. A scenario may already be in place whereby the indigenous invertebrate defoliators, which provide a high protein diet for the fledglings of the forest's avian pollinators and seed dispersers, has been decimated by exotic natural enemies. We may not only lose our distinctive bird fauna, but in the long term our forests as well.

On a positive note, bi-lateral risk assessment protocols between New Zealand and continental trading partners should recognise that island species are unlikely to be a threat to the biosecurity of continents. Slow growing island plants are unlikely competitors for continental plants, while island invertebrates are probably naïve in terms of defence and vulnerable to sophisticated continental predators.

\section{ACKNOWLEDGEMENTS}

This work was partially funded by MAF and New Zealand's Foundation for Research, Science \& Technology through contract C04X0302.

\section{REFERENCES}

Alma PJ 1986. Forest entomology in New Zealand. In: Levack H ed. Forestry Handbook, New Zealand Institute Foresters, Wellington, New Zealand. Pp. 33-38.

Anon. 1997. The state of our biodiversity. In: Smith I ed. The State of New Zealand's Environment 1997. Chapter. 9. Ministry for the Environment and GP Print, Wellington, New Zealand. $176 \mathrm{p}$.

Atkinson IAE, Cameron EK 1993. Human influence on the terrestrial biota and biotic communities of New Zealand. Trends in Ecology \& Evolution 8: 447-451.

Bain J 2003. Introduced forest and timber insects recorded from New Zealand indigenous hosts. Contractual Report to MAF, New Zealand Forest Research Institute Limited, Rotorua, New Zealand. 4 p.

Berenbaum MR 1995. The chemistry of defence: theory and practice. Proceedings National Academy Science 92: 2-8.

Campbell RW 1979. Gypsy Moth: Forest influence. USDAFS Agricultural Information Bulletin No. 423.

Carlquist S 1965. Island life. Natural History Press, Garden City, NY.

Case TJ 1990. Invasion resistance arises in strongly interacting species-rich model competition communities. Proceedings National Academy Science 87: 9610-9614.

Charles JG 1998. The settlement of fruit crop arthropod pests and their natural enemies in New Zealand: an historical guide to the future. Biocontrol News \& Information 19: $47 \mathrm{~N}-58 \mathrm{~N}$. 
D'Antonio CM, Dudley TL 1995. Biological invasions as agents of change on islands versus mainlands. In: Vitousek PM, Loope LL, Andersen H ed. Islands: biological diversity and ecosystem function Ecological Studies 115, Springer-Verlag, Berlin. Pp. 103-21.

Davies P 2005. The sum of the parts. New Scientist 2489: 34-37.

Elton CS 1958. The ecology of invasions by animals and plants. Methuen, London.

Erlich PR, Raven PH 1964. Butterflies and plants: a study in coevolution. Evolution 18: 586-608.

Fritts TH, Rodda GH 1998. The role of introduced species in the degradation of island ecosystems: a case history of Guam. Annual Review of Ecology and Systematics 29: 113-140.

Holt RD, Lawton JH, Polis GA, Martinez ND 1999. Trophic rank and the species-area relationship. Ecology 80(5): 1495-1504.

Hooper DU, Chapin FS, Ewel JJ, Hector A, Inchausti P, et al. 2005. Effects of biodiversity on ecosystem functioning: a consensus of current knowledge. Ecological Monographs 75 (1): 3-35.

Hubbell SP 2001: The unified neutral theory of biodiversity and biogeography. Princeton University Press, Princeton, USA. 375 p.

Itô Y, Miyashita K 1968. Biology of Hyphantria cunea (Lepidoptera: Arctiidae) in Japan. V. Preliminary life tables and mortality data in urban areas. Research Population Ecology X, 177-209.

Jaenike J 1990. Host specialisation in phytophagous insects. Annual Review of Ecology and Systematics 21: 243-273.

Johnston PR 2006. New Zealand's nonlichenised fungi - where they came from, who collected them, where they are now. National Science Museum Monographs 34: 37-49.

Kay MK 2003. Macroecology and the prediction of invasive invertebrate guilds. In: Goldson SL, Suckling DM ed. Defending the Green Oasis: New Zealand Biosecurity and Science. New Zealand Plant Protection Society, Christchurch, New Zealand. Pp. 93-100.

Kay MK 2004. An assessment of the risk to the New Zealand flora posed by Japanese strains of the gypsy moth Lymantia dispar and the fall web worm Hyphantria cunea. MAF contractual report, New Zealand Forest Research Institute Limited, Rotorua, New Zealand. 29 p.

Kay MK, Wratten SD 2006. Ecosystem function and the prediction of tree resistance to defoliators. In: Kamata N, Liebhold AM, Quiring DT, Clancy KM ed. Forest Insect Population and Host influences. Proceedings IUFRO Kanazawa International Symposium (2003). Pp. 78-80.

Kay M 2006. Are Island Forests Vulnerable to Invasive Defoliators? Strength in Simplicity. In: Paine TD ed. Invasive Forest Insects, Introduced Forest Trees, and Altered Ecosystems: Ecological Pest Management in Global Forests of a Changing World. Springer, The Netherlands. Pp. 1-13.

Kay MK, Gresham B, Hill RL, Zhang X 2008. The disintegration of the Scrophulariaceae and the biological control of Buddleja davidii. In: Julien MH, Sforza R, Bon MC, Evans HC, Hatcher PE, Hinz HL, Rector BG ed. Proceedings of the XII International Symposium on Biological Control of Weeds. CAB International, Wallingford, UK. Pp. 295-299.

Kennedy TA, Naeem S. Howe KM. Knops JMH. Tilman, D, Reich P. 2002. Biodiversity as a barrier to ecological invasion. Nature 417: 636-638.

Kolar CS, Lodge DM 2001. Progress in invasion biology: predicting invaders. Trends in Ecology \& Evolution 16: 199-204.

Kopf A, Rank NE, Roininen H, Julkunen-Tiitto R, Pasteels JM, Tahvanainen J 1998. The evolution of host-plant use and sequestration in the leaf beetle genus Phratora (Coleoptera: Chrysomelidae). Evolution 52: 517-528. 
Kriticos DJ, Phillips CB, Suckling DM 2005. Improving border biosecurity: potential economic benefits to New Zealand. New Zealand Plant Protection 58: 1-6.

Levine JM, Adler PB, Yelenik SG 2004. A meta-analysis of biotic resistance to exotic plant invasions. Ecological Letters 7: 975-989.

Lewinsohn TM, Novotny V. Basset Y. 2005. Insects on plants: diversity of herbivore assemblages revisited. Annual Review of Ecology and Systematics 36: 597-620.

Lill JT, Marquis RJ, Ricklefs RE 2002. Host plants influence parasitism of forest caterpillars. Nature 417: 170-173.

Long JD, Trussell GC, Elliman T 2009. Linking invasions and biogeography: Isolation differentially affects exotic and native plant diversity. Ecology 90: 863-868.

Lowe AD 1973. Insects. In: Williams GR ed The Natural History of New Zealand - an Ecological Survey. Reed, Wellington, New Zealand. Pp. 190-203.

MacArthur RH, Wilson EO 1967. The Theory of Island Biogeography. Princeton University Press, Princeton, USA. 203 p.

Maron JL, Vila M 2001. When do herbivores affect plant invasion? Evidence for the natural enemies and biotic resistance hypotheses. Oikos 95: 361-373.

Matsuki M, Kay M, Serin J, Floyd R, Scott JK 2001: Potential risk of accidental introduction of Asian gypsy moth to Australasia: effects of climatic conditions and suitability of native plants. Agricultural and Forest Entomology 3: 305-320.

May RM 1975. Patterns of species abundance and diversity. In: Cody ML, Diamond JM ed. Ecology and Evolution of Communities. Harvard University Press, Boston, USA. Pp. 81-120.

Meyer BS, Anderson DB, Böhning RH. 1960. Introduction to Plant Physiology. Van Nostrand, London.

Mitter C, Farrell B. Futuyma DJ 1991. Phylogenetic studies of insect-plant interactions: insights into the genesis of diversity. Trends in Ecology and Evolution 6: 290-293.

Moore PD 1995. Citation records show plant herbivory taking root as a hot research topic. The Scientist 26: 12.

Moulton MP, Pimm SL 1983. The introduced Hawaiian avifauna: biogeographic evidence for competition. American Naturalist 121: 669-690.

Ridley GS, Bain J, Bulman LS, Dick MA, Kay MK 2000. Threats to New Zealand's indigenous forests from exotic pathogens and pests. Science for Conservation 142. Department of Conservation, Wellington, New Zealand. 67 p.

Rosenzweig ML 1995. Species Diversity in Space and Time. Cambridge University Press, UK.

Schoenly K, Beaver RA, Heumier TA 1991. On the trophic relations of insects: a foodweb approach. American Naturalist 137: 597-638.

Stamp NE 2003. Out of the quagmire of plant defence hypotheses. Quarterly Review of Biology 78 (1): 1-40.

Stireman JO, Dyer LA, Janzen DH, Singer MS, Lill JT, Marquis RJ, Ricklefs RE, Gentry GL, Hallwachs W, Coley PD, Barone JA, Greeney HF, Connahs H, Barbosa P, Morais HC, Diniz IR 2005. Climatic unpredictability and parasitism of caterpillars: implications for global warming. Proceeding National Academy Science 102 (48): 17384-17387.

Strong DR, Lawton JH, Southwood R 1984. Insects on Plants: Community patterns and mechanisms. Blackwell Scientific Publications, Oxford, UK. 313 p.

Walsh PJ, Kay MK 1996. Insect threats and the risk to tree health. Tree Grower 30-33.

Wardle P 1985 Environmental influences on the vegetation of New Zealand. New Zealand Journal of Botany 23: 773-788.

Weisser WW, Siemann E 2004. The various effects of insects on ecosystem functioning. In: Weisser WW, Siemann E ed. Insects and Ecosystem Function. Ecological Studies 173, Springer-Verlag, Berlin. Pp. 3-24.

Whittaker RJ 1998. Island Biogeography. Oxford University Press, Oxford, UK. 285 p. 